\title{
Women Entrepreneurship Issues, Challenges and Empowerment through Self Help Groups: An Overview of Uttarakhand
}

\author{
P.N. Tiwari* \\ Department of Commerce, Government P.G. College, Rudrapur (U.S. Nagar), U.K. India \\ Email Id:drpntiwarirudra@gmail.com
}

\begin{abstract}
Entrepreneurship is one of the most important factors contributing to the economic development of the society. Entrepreneurs have been considered instrumental in initiating and sustaining socio-economic development. In India, concept of women entrepreneurship is of recent origin. Women have become aware about their rights and situations and entered in different fields of business. They have established their own successful business empires. They are contributing towards the growth of economy and improvement of their socio-economic conditions. Government of India has given due importance to women empowerment in the country and several schemes has been introduced for the upliftment of women entrepreneurs. Women workforce ratio in the country is increasing due to the increase in the women literacy rate in India. The concept of Self Help Groups (SHGs) is proved to be boon for the rural women in some states of India. It has not only raised their income but also their social status. Overview of the working of Self Help Groups (SHGs) in Uttarakhand is also depicted in this paper. This paper particularly focuses on various issues pertaining to women entrepreneur's issues, challenges and future perspective in India.

Keywords: Entrepreneurship, Women Entrepreneurs, Women workforce, Women Empowerment, Self Help Groups.
\end{abstract}

\section{PAPER/ARTICLE INFO} RECEIVED ON: 04/09/2019 ACCEPTED ON: 05/10/2019

Reference to this paper should be made as follows:

P.N. Tiwari (2019), “Women Entrepreneurship Issues, Challenges and Empowerment through Self Help Groups: An Overview of Uttarakhand", Int. J. of Trade and Commerce-IIARTC, Vol. 8, No. 2, pp. 275-288 
Women Entrepreneurship Issues, Challenges and Empowerment through Self Help Groups: An Overview of....... P.N. Tiwari

\section{INTRODUCTION}

Entrepreneurship is defined as the process by which individuals pursue opportunities without regard to resources they currently control. Despite years of legislative effort, women still face discrimination in the workforce. However, Small businesses being a leader in offering women opportunities for economic expression through entrepreneurship. Increasing number of women's are discovering the best way to break the "glass ceiling" that prevent them from rising to the top of many organizations is to start their own companies. Women performs $63 \%$ of the world's work, produce $50 \%$ of the food, but earn $10 \%$ of the income and own $1 \%$ of the property. Globally, women represent $49.6 \%$ of the total population, but only $40.8 \%$ of the total workforce in the formal sector (Women, Business and the Law, World Bank, 2018). Since ages India has been mendominated country. But, time is changing now. Women in India have outraged the fact that since hundreds of years they had been following the orders of men. Now they know their rights and duties and with the spreading awareness among the women they are not less than the men. They are walking with men at the same pace in each and every field. In earlier days, for women there were 3 Ks - Kitchen, Kids, Knitting, then came 3 Ps - Powder, Papad, Pickles and now at present there are 3 Es - Electronics, Energy, and Engineering.

Indian women had undergone a long way and are becoming increasingly visible and successful in all spheres and have shifted from kitchen to higher level of professional activities. Women entrepreneurs are fast becoming a force to reckon with in the business world and are not only involved in business for survival but to satisfy their inner urge of creativity and to prove their capabilities. Educated Women is contributing to a great extent to the social transformation and in the future, will be seen that more women venturing into areas traditionally dominated by men. Today, many women have established their own economy, i.e. entrepreneurial empire and are now ruling their world as they wished to. The hidden entrepreneurial potentials of women have gradually been changing with the growing sensitivity to the role and economic status in the society. Skill, knowledge and adaptability in business are the main reasons for women to emerge into business ventures.

"You can tell the condition of a nation by looking at the status of Women" -Jawaharlal Nehru

\section{WOMEN ENTREPRENEURSHIP STUDIES CONDUCTED IN INDIA AND ABROAD}

During 1990's, many women entered in the field of entrepreneurship to avail economic competence and independence, but many of them are observed to be not succeeding well as they had planned. Main reasons often are placed on the lack of enabling and sustaining facilities of entrepreneurial environment in general. Even then, there are success cases of women-run business units in India. In India, women with varied social, economic, political, regional and linguistic backgrounds constitute half the nation. The socio-economic condition of women is the key for overall growth and development of the country. A study conducted by Manickaval (1997) shows that $56 \%$ of the women are unemployed. Hence, development of women entrepreneurship is essential to provide economic opportunities to women.

Entrepreneur is the key factor of entrepreneurship and now women have been recognized as successful entrepreneurs as they have qualities desirable and relevant of entrepreneurship development. In the process of entrepreneurship, women have to face various problems associated with entrepreneurship and these problems get doubled because of her dual role as a 
wage earner and a homemaker. According to Reddi (1991) women entrepreneurs in Goa feel frustrated at times because they need to spare their time and energy, both towards their business as well as domestic affairs. Women in India constitute a larger proportion of total unemployed population and hence it is imperative to find out the entrepreneurial constraints faced by them.

Rathore and Chabra, (1991) in their paper on 'Promotion of Women Entrepreneurship - Training Strategies' state that Indian women find it increasingly difficult to adjust themselves to the dual role that they have to play as traditional housewives and compete with men in the field of business and industry. Working women are often tossed between home and work and experience mental conflicts as they are not able to devote the necessary units of time and energy to their home and children and find it mostly difficult and sometimes impossible to pursue as a career. A study by Surti and Surupia showed that the married migrated women entrepreneurs coming from nuclear families experience greater role stress than the unmarried local women entrepreneurs coming from joint families.

Srivastav and Chaudhary, (1995) in their work on 'Women Entrepreneurs: Problems Perspective and role expectations from banks, finds out that no single factor but a host of motivating factors act simultaneously on the individual creating dissonance in her, which in turn mores her to take an action directed towards elimination or reduction of dissonance in the individual. Women faced problems mainly in the areas of marketing of products and approaching the banks for getting loans. Personal problems like time constraint and family stress were also cited. The study concludes that joint family is not an obstacle for developing entrepreneurs. In fact, it is a facilitating factor. The entrepreneurial role enhances familial bonds and increases role satisfaction of women entrepreneurs as a wife, mother and maker of a 'home'.

Caputo and Dolinsky, (1998) have examined the role of financial and human capital of household member to pursue self-employment among females. The analysis revealed that business knowledge and cooperation of husband in family matters contribute a lot to pursue the business. Finding further suggested that government should provide necessary skill to women to ensure rapid growth of entrepreneurship.

\section{CONCEPT AND STATUS OF WOMEN ENTREPRENEURSHIP IN INDIA}

The women status in India has been subject to many great changes over the past few millennia. From equal status with men in ancient times through the low points of the medieval period, to the promotion of equal rights by many reformers, the history of women in India has been eventful. In modern India, women have adorned high offices in India including that of the President, Prime Minister, Speaker of the Lok Sabha and Leader of the Opposition. As of 2011, the President of India, the Speaker of the Lok Sabha and the Leader of the Opposition in Lok Sabha (Lower House of the Parliament) are all women.

Entrepreneurship has gained currency across the sphere and female-entrepreneurship had become an important module. India is one of the fastest emerging economies and the importance of entrepreneurship is realized across the gamut. According to the Government of India, "An enterprise owned and controlled by a women having a minimum financial interest of $51 \%$ of capital and giving at least $51 \%$ of the employment generated by the enterprise to women".

"Women Entrepreneurship" means an act of business ownership and business creation that empowers women economically increases their economic strength as well as position in 
Women Entrepreneurship Issues, Challenges and Empowerment through Self Help Groups: An Overview of....... P.N. Tiwari

society. "Women Entrepreneurship" is a person who accepts challenging role to meet her personal needs and become economically independent. A strong desire to do something positive is an inbuilt quality of entrepreneurial women, who is capable of contributing values in both family and social life.

Women in business are a recent phenomenon in India. By and large they had confided themselves to petty business and tiny cottage industries. Women entrepreneurs engaged in business due to push and pull factors, which encourage women to have an independent occupation and stands on their own legs. A sense towards independent decision-making in their life and career is the motivational factor behind this urge. Saddled with household chores and domestic responsibilities women want to get independence. Under the influence of these factors the women entrepreneurs choose a profession as a challenge and as an urge to do something new. Such situation is described as pull factors. While in push factors women engaged in business activities due to family compulsion and the responsibility is thrust upon them.

In rural India, agriculture and allied industrial sectors employ as much as $89.5 \%$ of the total female labour. In overall farm production, women's average contribution is estimated at $55 \%$ to $66 \%$ of the total labour. According to a 1991 World Bank report, women accounted for $94 \%$ of total employment in dairy production in India. Women constitute $51 \%$ of the total employed in forest-based small-scale enterprises.

\section{GROWTH OF WOMEN ENTREPRENEURSHIP IN INDIA}

Women entry into business is a new phenomenon in India,. Women entry into business, or say, entrepreneurship is traced out as an extension of their kitchen activities mainly to 3 Ps viz, pickles, powder and Papad. Women in India plugged into business for both pull and push factors. Pull factors imply the factors, which encourage women to start an occupation or venture with an urge to do something independently. Push factors refer to those factors, which compel to take up their own business to tide over their economic difficulties and responsibilities.

With growing awareness about business and spread of education among women over the period, women have started shifting from 3 Ps to engross to 3 modern E's, viz. Engineering, Electronics and Energy. They have excelled in these activities. Women entrepreneurs manufacturing solar cookers in Gujarat, small foundries in Maharashtra and T.V. capacitors in Orissa have proved beyond doubt that given the opportunities, they can excel their male counterparts. Smt. Sumati Morarji (Shipping Corporation), Smt. Yumutai Kirloskar (Mahila Udyog Limited), Smt. Neena Malhotra (Exports) and Smt. Shahnaz Hussain (Beauty Clinic) are some exemplary name of successful and accomplished women entrepreneurs in our country. There are several additional emerging sectors where women can exploit their hidden talent. These are:

- Eco-friendly technology

- Bio-technology

- IT enabled enterprises

- Event Management

- Tourism industry

- Telecommunication

- Vermiculture

- Mineral water

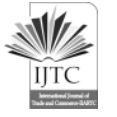


Women Entrepreneurship Issues, Challenges and Empowerment through Self Help Groups: An Overview of.......

- Sericulture

- Floriculture

- Herbal and health care

- Food, fruits and vegetable processing

\section{WOMEN EMPOWERMENT AND PLANNING PROCESS IN INDIA}

The all-round development of women has been one of the focal point of planning process in India. The First Five-Year Plan (1951-1956) envisaged a number of welfare measures for women. Establishment of the Central Social Welfare Board, organization of Mahila Mandals and the Community Development Programmes were a few steps in this direction. In the Second FiveYear Plan (1956-1961), the empowerment of women was closely linked with the overall approach of intensive agricultural development programmes. The Third and Fourth Five-Year Plans (19611966 and 1969-1974) supported female education as a major welfare measure.

The Fifth Five-Year Plan (1974-1979) emphasized training of women, who were in need of income and protection. This plan coincided with International Women's Decade and the submission of the report of the Committee on the Status of Women in India. In 1976, Women's Welfare and Development Bureau was set up under the Ministry of Social Welfare. The Sixth Five-Year Plan (1980-1985) saw a definite shift from welfare to development. It recognized women's lack of access to resources as a critical factor. The Seventh Five-Year Plan (1985-1990) emphasized the need for gender equality and empowerment. For the first time, emphasis was placed upon qualitative aspects such as inculcation of confidence, generation of awareness with regards to rights and training in skills for better employment.

The Eighth Five-Year Plan (1992-1997) focused on empowering women, especially at the grass roots level, through Panchayati Raj Institutions. The Ninth Five-Year Plan (1997-2002) adopted a strategy of women's component plan, under which not less than 30 percent of funds/benefits were earmarked for women-specific programmes. The Tenth Five-Year Plan (2002-2007) aims at empowering women through translating the recently adopted National Policy for Empowerment of Women (2001) into action and ensuring Survival, Protection and Development of women and children through rights-based approach.

The Eleventh Five-Year Plan (2007-2012) lays down six monitorable targets (1) Raise the sex ratio for age group 0-6 from 927 in 2001 to 935 by 2011-2012 and to 950 by 2016-2017; (2) Ensure that atleast $33 \%$ of the direct and indirect beneficiaries of all government schemes are women and girl children; (3) Reduce IMR from 57 to 28 and MMR from 301 to one per 1000 live births; (4) Reduce malnutrition among children of age group 0-3 to half its present level; (5) Reduce anemia among women and girls by $50 \%$ by the end of the Eleventh Plan; and (6) Reduce dropout rate for primary and secondary schooling by $10 \%$ for both girls as well as boys.

The Twelve Five-Year Plan (2012-2017) it is widely believed that men enjoy all the power and position, women were treated as second rate and lower human spheres. Twelfth five-year plan entitled as 'Faster Sustainable and More Inclusive Growth'. This plan had decided at the growth rate $8.2 \%$. The planning commission is pushing for special dispensation for single women participation in favour related work, both in agriculture and animal husbandry. In framing policies schemes for the twelfth five year plan, the special needs of women must be taken due care of the focus of the twelfth five year plan is on the health, education, urbanization and governance. 
Women Entrepreneurship Issues, Challenges and Empowerment through Self Help Groups: An Overview of....... P.N. Tiwari

\section{GOVERNMENT SCHEMES FOR WOMEN EMPOWERMENT}

The government programme for women development began as early as 1954 in India but the actual participation began only in 1974. At present, the Government of India has over schemes for women. Some of these are-
(i) Mudra Yojana Scheme
(ii) TREAD (Trade Related Entrepreneurship Assistance and Development)
(iii) Mahila Udyam Nidhi Scheme
(iv) Annapurna Scheme
(v) Stree Shakti Package for Women Entrepreneurs
(vi) Bhartiya Mahila Business Loan
(vii) Dena Shakti Scheme
(viii) Udyogini Scheme
(ix) Cent Kalyani Scheme
(x) Sabala Yojana
(xi) Kishori Shakti Yojana
(xii) Pradhan Mantri Matra Vandana Yojana (PMMVY)
(xiii) Women Empowerment Mission.
(xiv) Swadhar
(xv) State Resource Center for Women (SRCW)
(xvi) Beti Bachao Beti Padhao Scheme
(xvii) Sanitary Napkin Sparsh
(xviii) Uttarakhand Women Integrated Development Scheme
(xix) Nanda Gaura Yojana
(xx) Working Women Hostel
(xxi) Tilu Rauteli Award
(xxii) Uttarakhand State Commission for Women
(xxiii) Mukhyamantri State Aajivika Yojana
(xxiv) Aanganwadi Karmi Kalyan Kosh

The efforts of government and its different agencies are supplemented by non-governmental organization that are playing an equally important role in facilitating women empowerment. Despite concerted efforts of governments and NGOs there are certain gaps. Of course we have come a long way in empowering women yet the future journey is difficult and demanding.

\section{STATE-WISE SSI IN INDIA OWNED BY WOMEN ENTREPRENEURS}

In India small scale industrial units are owned both by men and women. Table 1 reveals that among the small scale industrial units owned by women entrepreneurs in India, Kerala tops the list with 1.39 Lakh units, followed by Tamil Nadu with 1.29 Lakh units. Tamil Nadu ranks second in the total number of small-scale units owned by women entrepreneurs in India. Lakshadweep has the lowest number of small-scale units owned by women entrepreneurs (67 units). The total number of women enterprises in the total SSI Sector was estimated at 10,63,721 (10-11\%). The estimated number of enterprises actually managed by women was 9,95,141 (9.46\%). In the States of Mizoram, Orissa, Karnataka, Goa, Lakshadweep, Kerala, Tamil Nadu and Pondicherry the 
Women Entrepreneurship Issues, Challenges and Empowerment through Self Help Groups: An Overview of.......

P.N. Tiwari

share of women employment was significantly higher (more than $20 \%$ ). The position of women entrepreneurships and women enterprises is given State-wise in the following table-

TABLE - 1: PARTICIPATION OF WOMEN IN MANAGEMENT/OWNERSHIP IN SSI SECTOR

\begin{tabular}{|c|c|c|c|}
\hline S. No. & Name of State/ UT & $\begin{array}{c}\text { No. of Enterprises Managed } \\
\text { by Women }\end{array}$ & $\begin{array}{l}\text { No. of Women } \\
\text { Enterprises }\end{array}$ \\
\hline 1. & Jammu \& Kashmir & 5640 & 5742 \\
\hline 2. & Himachal Pradesh & 3515 & 3722 \\
\hline 3. & Punjab & 30190 & 29068 \\
\hline 4. & Chandigarh & 2059 & 2243 \\
\hline 5. & Uttaranchal & 8706 & 8804 \\
\hline 6. & Haryana & 10087 & 9620 \\
\hline 7. & Delhi & 13368 & 14383 \\
\hline 8. & Rajasthan & 29785 & 36371 \\
\hline 9. & Uttar Pradesh & 54491 & 72667 \\
\hline 10. & Bihar & 38170 & 49443 \\
\hline 11. & Sikkim & 30 & 98 \\
\hline 12. & Arunachal Pradesh & 131 & 150 \\
\hline 13. & Nagaland & 207 & 179 \\
\hline 14. & Manipur & 9168 & 10745 \\
\hline 15. & Mizoram & 3076 & 3700 \\
\hline 16. & Tripura & 631 & 863 \\
\hline 17. & Meghalaya & 3658 & 3580 \\
\hline 18. & Assam & 11189 & 11757 \\
\hline 19. & West Bengal & 71847 & 69625 \\
\hline 20. & Jharkhand & 7271 & 7865 \\
\hline 21. & Orissa & 33274 & 38233 \\
\hline 22. & Chhattisgarh & 11766 & 10034 \\
\hline 23. & Madhya Pradesh & 62351 & 68823 \\
\hline 24. & Gujarat & 55361 & 53703 \\
\hline 25. \&26. & $\begin{array}{l}\text { Daman \& Diu and Dadar \& Nagar } \\
\text { Haveli }\end{array}$ & 167 & 213 \\
\hline 27. & Maharashtra & 80662 & 100670 \\
\hline 28. & Andhra Pradesh & 77347 & 77166 \\
\hline 29. & Karnataka & 101264 & 103169 \\
\hline 30. & Goa & 677 & 810 \\
\hline 31. & Lakshadweep & 61 & 67 \\
\hline 32. & Kerala & 137561 & 139225 \\
\hline 33. & Tamil Nadu & 130289 & 129808 \\
\hline 34. & Pondicherry & 1089 & 1065 \\
\hline \multirow[t]{2}{*}{35.} & Andaman \& Nicobar Islands & 53 & 110 \\
\hline & All India & 995141 & 1063721 \\
\hline
\end{tabular}

Source: RBI Annual Report 2018-2019.

About $13 \%$ of the women enterprises were in the registered SSI sector and the remaining $87 \%$ were in the unregistered SSI sector. With regard to the enterprises managed by women, $11.5 \%$ were in the registered SSI sector and $88.5 \%$ were in the unregistered SSI sector. The share of the 
Women Entrepreneurship Issues, Challenges and Empowerment through Self Help Groups: An Overview of....... P.N. Tiwari

units managed by women in terms employment was 7.14. The employment generated per Rs. one Lakh investment in the units managed by women was 2.49. Principal Characteristics of SSI units managed by women are presented in the following table.

TABLE-2: PRINCIPAL CHARACTERISTICS OF SSI UNITS MANAGED BY WOMEN (Rs. In lakhs)

\begin{tabular}{|c|c|c|c|c|c|c|}
\hline $\begin{array}{c}\text { For Units Managed by } \\
\text { Women }\end{array}$ & $\begin{array}{l}\text { No. of } \\
\text { Units }\end{array}$ & $\begin{array}{c}\text { Market Value } \\
\text { of Fixed } \\
\text { Assets } \\
\text { (Rs.) } \\
\end{array}$ & $\begin{array}{c}\text { Original Value } \\
\text { of Plant \& } \\
\text { Machinery } \\
\text { (Rs.) }\end{array}$ & \begin{tabular}{|c|} 
Employme \\
nt (Number \\
of \\
Employees)
\end{tabular} & $\begin{array}{c}\text { Gross } \\
\text { Output } \\
\text { (Rs.) }\end{array}$ & $\begin{array}{l}\text { Exports } \\
\text { (Rs.) }\end{array}$ \\
\hline Regd. SSI Sector & 114362 & 336245.71 & 110478.53 & 349342 & 603168.34 & 33148.23 \\
\hline $\begin{array}{l}\text { Percentage to total of the } \\
\text { respective category }\end{array}$ & 8.32 & 3.66 & 3.64 & 5.67 & 2.97 & 2.69 \\
\hline Unread SSI Sector & 580780 & 377633.18 & 114961.16 & 1429962 & 373248.25 & 538.02 \\
\hline $\begin{array}{l}\text { Percentage to total of the } \\
\text { respective category }\end{array}$ & 9.63 & 6.04 & 4.68 & 7.62 & 4.72 & 0.28 \\
\hline Total SSI Sector & 995142 & 71387.88 & 225439.68 & 1779304 & 976416.58 & 33686.25 \\
\hline $\begin{array}{l}\text { Percentage to total of the } \\
\text { respective category }\end{array}$ & 9.46 & 4.63 & 4.11 & 7.14 & 3.46 & 2.37 \\
\hline
\end{tabular}

Source: MSME, Annual Report 2018.

\section{PROBleMS OF WOMEN ENTREPRENEURSHIP IN INDIA}

Women entrepreneurs encounter two sets of problems, viz. general problems of entrepreneurs and problems specific to women entrepreneurs. These problems are discussed as follows:

(i) Problem of Finance : Finance is regarded as "life blood" for any enterprise, be it big or small. However, women entrepreneurs suffer from shortage of finance on two counts. Firstly, women do not generally have property on their names to use them as collateral for obtaining funds from external sources. Thus, their access to the external sources of funds is limited. Secondly, the banks also consider women less credit-worthy and discourage women borrowers on the belief that they can at any time leave their business. In such a situation, women entrepreneurs are bound to rely on their own savings or loans from friends and relatives. Thus, women enterprises fail due to the shortage of finance.

(ii) Scarcity of Raw Material: Most of the women enterprises are plagued by the scarcity of raw material and necessary inputs. Added to this are the high prices of raw material, on the other. The failure of any woman co-operatives in 1971 engaged in basket making is an example how the scarcity of raw material sounds the dearth-knell of enterprises run by women.

(iii) Tough Competition: Women entrepreneurs do not have organization set up to pump in a lot of money for canvassing and advertisement. Thus, they have to face a tough competition for marketing their products with both organized sector and their male counterparts. Such a competition ultimately results in the liquidation of women enterprises.

(iv) Limited Mobility: Unlike men, women mobility in India is highly limited due to various reasons. A single woman asking for room is still upon suspicion. Cumbersome exercise involved in starting an enterprise coupled with the officials humiliating attitude towards women compels them to give up an idea of starting an enterprise. 
Women Entrepreneurship Issues, Challenges and Empowerment through Self Help Groups: An Overview of.......

P.N. Tiwari

(v) Family Ties: In India, it is mainly a woman's duty to look after the children and other members of the family. Man plays a secondary role only. In case of married woman, she has to strike a fine balance between her business and family. Her total involvement in family leaves little or no energy and time to devote for business. Support and approval of husbands seem necessary condition or women's entry in to business. Accordingly, the educational level and family background of husbands positively influence women's entry into business activities.

(vi) Lack of Education: In India, around three-fifths of women are still illiterate. Illiteracy is the root cause of socio-economic problems. Due to the lack of education and that too qualitative education, women are not aware of business, technology and market knowledge. Also, lack of education cases low achievement motivation among women. Thus, lack of education creates problems for women in the setting up and running of business enterprises.

(vii) Male dominated society: Male chauvinism is till the order of the day in India. The constitution of India speaks of equality between sexes. But in practice women are looked upon as able, i.e. weak in all respects. Women suffer from male reservations about a women's role, ability and capacity and are treated accordingly. In nutshell, in the male dominated Indian society, women are not treated equal to men. This in turn, serves as a barrier to women entry into business.

(viii) Low Risk bearing ability: Women in India lead a protected life. They are less educated and economically not self-dependent. All these reduce their ability to bear risk involved in running an enterprise. Risk bearing is an essential requisite of a successful entrepreneur. In addition to above problems, inadequate infra structural facilities, shortage of power, high cost of production, social attitude, low need for achievement and socio-economic constraints also hold the women back from entering into business.

\section{TOP 10 WOMEN ENTREPRENEURS AND LEADERS OF INDIA: AN OVERVIEW}

The Indian women are no longer treated as show pieces to be kept at home. They are also enjoying the impact of globalization and making an influence not only on domestic but also on international sphere. Women are doing a wonderful job striking a balance between their house and career. Women are achieving success in almost every field, 'Business' is also one of them. There are more than $14 \%$ of businesses which are owned and managed by women entrepreneurs and the numbers keep increasing. There are many successful and famous women entrepreneurs in India who are doing great in their fields. Here I'm going to list Top 10 Most Successful and Famous Indian Women Entrepreneurs (2019) who are the great examples as well as source of inspiration for upcoming entrepreneurs:

(i) Falguni Nayar - Founder of Nykaa: Falguni Nayar (Falguni Sanjay Nayar) is one of those most famous and successful women entrepreneurs in India who possess a dream of doing something big, and that she did! She is now a successful entrepreneur who runs a company with a valuation of 200crs. Falguni has done her post-graduation Diploma in Management from IIM(Indian Institute of Management), Ahmadabad. She was the former Managing Director at Kotak Mahindra Capital Co. for more than 18 years. She gave up her job in 2012 to pursue her dreams of becoming a women entrepreneur. After quitting her job, she 
Women Entrepreneurship Issues, Challenges and Empowerment through Self Help Groups: An Overview of.......

P.N. Tiwari

decided to start a multi-brand beauty store named "Nykaa". She got this business idea when she was shopping on an International multi-brand beauty store, Sephora. She felt the need to replicate that in India, and that's how the Nykaa was started. Nykaa is an ecommerce store that deals in beauty and wellness products from all the leading brands like Lakmé, Kaya Skin Clinic, L'Oréal Paris, and more. It has its offline presence in 17+ stores and expanding. It has over $850+$ curated brands and 35,000 products.

(ii) Neeru Sharma - Co-Founder at Infibeam: Neeru Sharma holds an MBA from Carnegie Mellon University and an Engineering degree in Computer Science. She is one of the founders or we can say a co-founder at Infibeam. Infibeam was started in 2007, it's an online eCommerce store for books, electronics, and automobiles in India. Infibeam is listed on the BSE and the National Stock Exchange of India and Infibeam also became India's first eCommerce company to file an IPO, in July 2015 Neeru Sharma heads all of Corporate Development at Infibeam, which includes strategic thinking, new business model evaluation, and implementation, formulating and handling strategic alliances and representing Infibeam in the eCommerce arena.

(iii) Radhika Ghai Aggarwal - Co-Fonder of Shopclues: Radhika Ghai Aggarwal is the Cofounder at ShopClues. She is also the first woman entrepreneur from India to enter the Unicorn Club. Radhika holds an MBA from Washington University and has also studied Web 2.0 and Creative Writing from Stanford. In fact, ShopClues is also not Radhika's first entrepreneurial venture. She had earlier started a company which was a content portal for NRI women, known as "FashionClues". ShopClues is an online eCommerce store, just like Flipkart and Amazon which is owned by Clues Network Pvt. Ltd. ShopClues raised funding of US\$100 million from Tiger Global Management and joined the Unicorn Club in January 2016.

(iv) Richa Kar - Founder of Zivame: Richa Kar - the founder of Zivame, become a successful women entrepreneur by starting India's biggest online retailer of lingerie.In 2011, Richa realized that lingerie is an under-served category in India. That's how she decided to start Zivame which was accepted by the Indian Women's as it's a comfortable way of shopping for innerwear online in India. Zivame runs by Actoserba Active Wholesale Pvt. Ltd., which is a Bengaluru based company launched in 2011. Zivame is now also extending into multiple categories and channels. It has it's a presence in more than 26 retail stores and over 600 multi-brand outlets along with the reach across India through its online channel. It also becomes India's flagship omnichannel lingerie brand. Zivame has raised total funding of $\$ 57.6$ million since it was established.

(v) Sabina Chopra - Co-Founder in Yatra: Sabina Chopra - the co-founder at Yatra, she is one the most successful women entrepreneurs in India having more than 16 years of work experience with ebookr which is Europe's Largest Travel Company in India. She has her Bachelor of Arts degree from Delhi University. Sabina launched Yatra.com in 2006 along with two co-founders, Dhruv Shringi and Manish Amin. Yatra is basically an online portal or an online travel agency to book hotels, flight tickets, bus and train tickets, and holiday 
Women Entrepreneurship Issues, Challenges and Empowerment through Self Help Groups: An Overview of.......

P.N. Tiwari

packages in India and abroad. The company is based in Gurugram. It also became the second-largest online travel service provider in India on April 2012. Yatra has raised more than $\$ 50$ million funds in 4 rounds of funding.

(vi) Sairee Chahal - Founder of Sheroes: Sairee Chahal - the founder and CEO of SHEROES, which is not her first venture. She also has another venture known as Fleximoms, that's the place from where she got the idea of SHEROES and become a successful women entrepreneur in India. SHEROES is an online destination for women from where they can get advice on a particular profession and explore different career opportunities. Sairee established SHEROES in January 2014 with a mission of helping women to find the perfect career and make their life better. SHEROES also runs the only women career helpline in the world which is operated by a team of career counselors and coaches. They help women by offering them support, advice, and resources.

(vii) Shradha Sharma- Founder of Your Story: Shradha Sharma is the founder of YourStory which is a media technology platform for entrepreneurs. She is also one of the top bloggers in India. Before starting YourStory, She served as an assistant vice president at CNBC TV18 and also a brand adviser at The Times of India. Shradha founded YourStory in 2008, with the mission to tell stories that matter, stories with heart, with a drive. YourStory have published more than 70,000 stories of entrepreneurs and change-makers and helped more than 50,000 entrepreneurs' access networking and funding opportunities. YourStory stands tall with a database of over 70,000 stories where she leads the team of over 100 people who offer the content in 11 different local languages and having a reader-base of more than a million.

(viii) Suchi Mukherjee - Founder of LimeRoad: Suchi Mukherjee - the founder of Lime Road, is an Indian Women Entrepreneur who started her entrepreneurial journey in 2012 when he was on maternity leave. Suchi lives in Haryana with her husband and has two children. In 1998, Suchi started her career with Lehman Brothers Inc., and in 2003, she joined Virgin Media as Director of Change and Business Development. She also worked in eBay, Skype, and Gumtree later. LimeRoad was founded in 2012, it's an online eCommerce store which deals in fashion, lifestyle, and accessories. LimeRoad also has reported an increase in revenue of about 78.5 percent in February 2019.

(ix) Upasana Taku - Founder of Zaakpay, Co-Founder in Mobikwik: Upasana Taku - the founder of ZaakPay and Co-Founder in Mobikwik is Indian Women Entrepreneur who now runs Mobikwik which now become India's largest independent mobile payments network and ZaakPay which is an online payment gateway. Upasana has worked with HSBC and Paypal, which helps her in getting a good knowledge and background in payments. In April 2009, She founded MobiKwik with Bipin Preet Singh and in October 2017, they have launched ZaakPay which an online payment gateway for MobiKwik.

(x) Vandana Luthra - Founder of VLCC: Vandana Luthra - the founder of VLCC Health Care Limited is an Indian women entrepreneur who has expertise in beauty, fitness, food nutrition and skincare. She studied all this from Germany, UK, and France. In 1989, 
Women Entrepreneurship Issues, Challenges and Empowerment through Self Help Groups: An Overview of....... P.N. Tiwari

Vandana started VLCC which is a beauty and slimming services center in Safdarjung Development Area, New Delhi. VLCC is currently operating more than 326 locations in 153 cities and 13 countries. Vandana was also ranked 26th in the distinguished annual Forbes Asia 2016 list which is of 50 Power Businesswomen in the APAC region (which includes Asia, Australia, and New Zealand).

Women like these are an inspiration for all other women who strive to achieve great heights in their lives. Taking them as our role models, each one of us can be there where they are right now. All we need have is faith in ourselves, confidence and above all a fixed aim that we need work towards.

\section{Women EmpoWerment Through SElf HelP Groups (SHGs): AN Overview OF UTTARAKHAND}

The scheme, Development of Women and Children in Rural Areas (DWCRA) launched in 1982-83 (presently called as SHGs), inaugurated an era for systematically organizing women in groups for providing them opportunities of self-employment on a sustained basis. Several thousands of rural women from the length and breadth of the country participate in this programme and they have taken up a number of trades under DWCRA banner. The programme called for formation of groups of 10-15 women who could collectively engage in an activity. One woman amongst the members functions as the group organizer who helps in the choice of activity, procurement of raw materials, marketing of products etc.

A revolving fund of Rs. 15,000/- (subsequently increased to Rs. 20,000/-) was made available to each group for credit and administrative needs. The programme is implemented by the District Rural Development Agency (DRDA) at the district level. SHG is the only programme of its kind, which aims at empowering the rural poor women by inculcating entrepreneurial skill. It seeks to encourage collective action in the form of group activities, which are known to work better than individual efforts.

As per official census of India 2011 population of Uttarakhand is having 100.86 lakh showing change of $18.81 \%$ from last decade. Uttarakhand feeds $0.83 \%$ of total population of India. As per preliminary report of Uttarakhand out of total population of 10086292 male and female constituted 5137773 and 4948519 respectively. Uttarakhand is also one of the state were women empowerment is on rise and entrepreneurial activities are increasing. According to census report 2011 literacy rate among women is $70.70 \%$ with regard to sex ratio, Uttarakhand is having 963 more than India's average sex ratio, i.e. 940. Female work force participation in the Uttarakhand is $44.2 \%$ higher than other major states and much higher than that of India's average $(26.0 \%)$.

The 6392 registered Mahila Mandals in the state. Cash awards are given to these who perform well. They works in the village to eradicate liquor shop and to promote women's economic employment generation for women through the formation of Self Help Groups in rural areas for raising the per capital income of women.

An important achievement is that loan repayment of $94 \%$ of those SHGs is $100 \%$. Moreover, a group of members of SHGs (Nainital \& Dehradun districts) travelled to one of the South Indian states in 2005-06 on field trip and are now implementing the lessons - Learnt from the experience 
Women Entrepreneurship Issues, Challenges and Empowerment through Self Help Groups: An Overview of.......

P.N. Tiwari

of their counterpart. The SHGs are involved in a wide range of economic activities, such as agro business, handicraft, floriculture, tailoring and carpentry, running of fair price shops, etc. in order to be gainfully employed and augment household of Mahila Mandals and SHGs have raised the level of women's involvement in household decision making. The NFMS IV (2016) report maintains that in Uttarakhand $58.5 \%$ of women have access to surplus money as compared to $45.6 \%$ in Haryana and $54.6 \%$ in Uttar Pradesh.

\section{SPECIFIC ObJeCTIVES OF THE SCHEME}

The specific objective of the scheme is to improve the socio-economic conditions of rural women and creating employment opportunities. The specific objectives are :

(i) To help and promote self-employment among the rural women, who are below the poverty line, by providing skill training, which are acceptable to the beneficiaries, by encouraging productivity in their existing work and by introducing new activities hitherto undertaken.

(ii) To organize the beneficiaries in groups, activity-wise and promote economic and social selfreliance;

(iii) To generate income for the rural poor by creating avenues for production of goods and services;

(iv) To organize production enhancing programmes in rural areas;

(v) To provide for care of the children of the working women by providing an improved environment, care and food by establishing crèches/balwadis.

\section{FUtURE Perspective OF WOMEN ENTREPRENEURSHIP IN INDIA}

The country needs to mobilize and utilize fully all its resources including human resources. The participation of women in economic activities is necessary not only from a human resource point of view but also is essential even from the objective of raising the status of women in the society. The economic status of the women is now accepted as an indicator of a society's stage of development and therefore, it becomes imperative for the government to frame policies for development of entrepreneurship among women. The long-term objectives of the development programmes for women should aim to raise their economic and social status in order to bring them into the mainstream of national life and development. For this, due recognition has to be accorded to the role and contribution of women in the various social economic and political and cultural activities.

\section{REFERENCES}

[1]. Brush, C.G. (1992), Research on women business owners, past trends, a new perspective and future dimensions; Entrepreneurship Theory and Practice as in Fenwick T. Women Entrepreneurs: A critical review of literature.

[2]. Caputo R.K. and Dolinsky, Arthur (1998), "Women's Choice of Pursue Self-Employment : The Role of Financial and Human Capital of Household Members". Journal of Small Business Management, Vol. 36(2), pp. 8-18.

[3]. Census of India Report, 2011.

[4]. H.H. Stevenson and J.C. Jarillon (1990) "A Paradigm for entrepreneurship: Entrepreneurial Management" Strategic Management Journal 11, pp. 17-27. 
Women Entrepreneurship Issues, Challenges and Empowerment through Self Help Groups: An Overview of.......

P.N. Tiwari

[5]. Manickavel, S. (1997), Small Industries: "Need for entrepreneurs in villages", Social Welfare 32(7); pp. 19-21.

[6]. Ministry of Micro, Small and medium Enterprises, Annual Report-2018.

[7]. Punetha, M. Sangeeta, S. Padmawati (1999), "Women Entrepreneurs : Their problems and constraints", Indian Journal of Labour Economics, Vol. 42, No. 4, pp 701-706.

[8]. Rathore, B.S. and Chabra, Rama (1991), "Promotion of Women Entrepreneurship Training Strategies", SEDME.

[9]. Reddi, P.N. (1991), "Problems of Women Entrepreneurs in Goa : A pilot suty", Khadi Gramodyog, 37(4); 157-159.

[10]. Reserve Bank of India, Annual Report- 2017-18 and 2018-19.

[11]. Singh, K.P., "Women Entrepreneurs: Their Profile and Motivation", The Journal of Entrepreneurship, 2(1).

[12]. Srivastav, A.K. and Chaudhary, Sanjay (1991): "Women Entrepreneurs - Problems, Perspective and Role Expectations from Banks", Thesis Punjab University, Chandigarh. 